\title{
Skema Model Vertikultur dan Implikasinya Bagi Pemberdayaan Masyarakat Studi Kasus: Desa Salam Karangpandan Sukoharjo
}

\author{
Yogi Pasca Pratama, Bhimo Rizky Samudro, Albertus Maqnus Soesilo \\ (Fakultas Ekonomi dan Bisnis Universitas Sebelas Maret) \\ yogipasca@staff.uns.ac.id, bhimosamudro@staff.uns.ac.id, \\ albertussoesilo@staff.uns.ac.id
}

Email korespondensi: bhimosamudro@staff.uns.ac.id

\begin{abstract}
ABSTRAK
Skema pemberdayaan desa sehat dapat dilakukan dengan visi utama peningkatan perekonomian masyarakat desa. Peran serta dan rasa memiliki masyarakat desa menjadi modal utama agar masyarakat yang bersangkutan dapat melakukan aktivitas perekonomiannya secara mandiri dan berkelanjutan. Metode yang dilakukan oleh pemberdayaan di desa Salam adalah dengan sistem inovasi pertanian baru dengan pola tanam ke atas yaitu vertikultur. Sistem budidaya pertanian secara vertikal atau bertingkat ini merupakan konsep penghijauan yang cocok untuk daerah dengan lahan terbatas, dan atau pengalihfungsian lahan pekarangan warga yang tidak bernilai ekonomis menjadi memiliki nilai panenan. Misalnya, lahan 1 meter mungkin hanya bisa untuk menanam 5 batang tanaman, dengan sistem vertikal dapat mencakup 20 batang tanaman.Vertikultur organik adalah budidaya tanaman secara vertikal dengan menggunakan sarana media tanam, pupuk, dan pestisida yang berasal dari bahan organik non kimiawi. Tanaman organik yang dapat dibudidayakan dan sesuai dengan sistem vertikultur adalah jenis tanaman sayur-sayuran dan tanaman obatobatan yang memiliki perakaran yang dangkal dan memiliki berat yang relatif ringan sehingga tidak akan terlalu membebani media tanam vertikultur pada pertumbuhan tanaman tersebut.
\end{abstract}

Kata kunci: desa, pemberdayaan, vertikultur

\section{ABSTRACT}

$A$ healthy village empowerment scheme can be carried out with the main vision of improving the economy of rural communities. The participation and sense of belonging to the village community are the main capital so that the people concerned can carry out their economic activities independently and sustainably. Healthy villages are one proof of village independence in carrying out life at the grassroots level. In reality various problems at the grassroots level are real life phenomena, in which the community conducts direct activities in contact with natural resources. The values that apply at the village level are a challenge that must be faced to support the creation of healthy villages. The method employed by empowerment in the village of Salam is a new agricultural innovation system with an upward cropping pattern, namely verticulture. This vertical or multilevel agricultural cultivation system is a concept of reforestation that is suitable for areas with limited land, and / or the conversion of functions of people's land that is of no economic value to have a harvest value. For example, 1 meter of land may only be able to plant 5 stems of plants, with a vertical system that can be used for 20 plants. Meanwhile, organic verticulture is vertical crop cultivation using the means of planting media, fertilizers, and pesticides derived from non-chemical organic materials.

Keywords: empowerment, village, verticulture 


\section{PENDAHULUAN}

Desa Salam termasuk salah satu desa dari 11 (sebelas) desa di wilayah kecamatan Karangpandan Kabupaten Karanganyar. Desa Salam memiliki luas wilayah 230,9035 Ha. Ketinggian tanah dari permukaan air laut 600 meter. Desa Salam terdiri dari 4 dusun, 8 RW, dan 16 RT. Rincian pembagian wilayah pada tiap-tiap dusun yaitu terdiri dari $2 \mathrm{RW}$ dan 4 RT. Dusun yang terdapat di Desa Salam yaitu Dusun Bulu, Dusun Gedangan, Dusun Salam, dan Dusun Cempo. Jumlah penduduk Desa Salam adalah 3136 orang dan 825 Kepala Keluarga (KK). Jumlah penduduk tersebut terbagi dalam 1567 jiwa laki-laki dan 1569 jiwa perempuan. Pendidikan di Desa Salam cukup berkembang sebanyak 5 orang tidak tamat SD, 1.892 orang lulusan SD, 617 orang lulusan SMP, 460 orang lulusan SMA, 134 orang lulusan sarjana muda (D-3), dan 25 orang sarjana (S-1).

Kondisi ekonomi Desa Salam merupakan desa pertanian, karena masyarakatnya sebagian bekerja dalam bidang pertanian, sedangkan yang lainnya adalah PNS, buruh, pedagang, dan lain-lain, sebagaimana dalam tabel struktur mata pencaharian penduduk sebagai berikut :

Tabel 1 Struktur Mata Pencaharian

\begin{tabular}{lll}
\hline No & Mata Pencaharian & Jumlah \\
\hline 1 & PNS & 63 \\
2 & Buruh & 1.292 \\
3 & Petani & 412 \\
4 & Pedagang & 64 \\
5 & Pengusaha & 89 \\
6 & TNI/Polri & 5 \\
7 & Pensiunan & 15 \\
8 & Lain-lain & 92 \\
\hline
\end{tabular}

Sumber: Data monografi Desa Salam, 2015

\section{Desa Salam dengan mayoritas mata pencaharian petani dengan} pendapatan per kapita rata-rata $\mathrm{Rp}$ $600.000,00$ per bulan dengan kategori desa sedang diantara 11 desa di Kecamatan Karangpandan. Adapun industri lokal/home industry yang ada di Desa Salam adalah anyaman bambu, konveksi, dan pembuatan makanan tradisional. Model yang dikembangkan berbasis pada ri tingkat kesejahteraan masyarakat mulai dari kelompok masyarakat miskin, menengah sampai kaya.. Masyarakat menyampaikan secara terbuka tentang kriteria rumah tangga miskin yang selanjutnya telah ditetapkan di tingkat Desa Salam. Adapun kriteria rumah tangga miskin adalah:

1) Memiliki rumah sangat sederhana

2) Tidak memiliki MCK

3) Penghasilan di bawah UMK Karanganyar
4) Pendidikan rendah dan/atau tidak tamat SD

Dengan kriteria di atas maka Rumah Tangga Miskin (RTM) berjumlah 1.011 jiwa, terdiri dari 405 orang laki-laki dan 566 orang perempuan.

Bidang sosial dan budaya di Desa Salam dekat dengan budaya Jawa seperti budaya gotong-royong dan menjunjung tinggi nilai-nilai luhur yang telah diwariskan oleh para leluhur. Bidang sosial kemasyarakatan Desa Salam juga beraneka ragam dalam bermasyarakat karena di Desa Salam juga terdapat penduduk yang berasal dari luar pulau Jawa sehingga semakin banyak budaya yang dimiliki oleh masyarakat di Desa Salam.

Potensi unggulan Desa Salam dalam mengembangkan perekonomian antara lain usaha pertanian berupa padi, ubi, dan sayuran, usaha industri 
pengolahan pangan, usaha peternakan, dan usaha perdagangan. Dengan berbagai data kemasyarakatan, data riil potensi desa, dan potensi unggulan, maka sistem pertanian berbasis vertikultur organik cukup memadai untuk ditumbuhkembangkan demi tercapainya desa sehat non-kimiawi berbasis sayuran organik. Nilai ekonomis sayuran organik yang lebih tinggi dari sayuran pembudidayaan secara konvensional cukup menarik untuk diperkenalkan kepada masyarakat.

Model, bahan, ukuran, wadah $\mathrm{v}$ ertikultur sangat banyak, dapat relatif mudah untuk disesuaikan dengan kondisi dan keinginan pribadi. Pada umumnya adalah berbentuk persegi panjang, segi tiga, atau dibentuk mirip anak tangga, dengan beberapa undakundakan atau sejumlah rak. Bahan dapat berupa bambu atau pipa paralon, kaleng bekas, bahkan lembaran karung beras sekalipun, karena salah satu filosofi dari vertikultur adalah memanfaatkan benda-benda bekas.

Persyaratan vertikultur adalah $\mathrm{k}$ uat dan mudah dipindah-pindahkan. Tanaman yang akan ditanam sebaiknya disesuaikan dengan kebutuhan dan memiliki nilai ekonomis tinggi, berumur pendek, dan berakar pendek. Tanaman sayuran yang sering dibudidayakan secara vertikultur antara lain selada, kangkung, bayam, katuk, kemangi, tomat, pare, kacang panjang, mentimun dan tanaman sayuran lainnya.

Untuk tujuan komersial, penge mbangan vertikultur ini perlu dipertim bangkan aspek ekonomisnya agar biaya produksi jangan sampai melebihi pendapatan dari hasil penjualan tanaman. Sedangkan untuk hobi, vertikultur dapat dijadikan sebagai media kreativitas dan memperoleh panenan yang sehat dan berkualitas.

Kelebihan sistem pertanian vertikultur: (1) efisiensi penggunaan lahan karena yang ditanam jumlahnya lebih banyak dibandingkan sistem konvensional, (2) penghematan pemakaian pupuk dan pestisida, (3) kemungkinan tumbuhnya rumput dan gulma lebih kecil, (4) dapat dipindahkan dengan mudah karena tanaman diletakkan dalam wadah tertentu, (5) mempermudah monitoring/pemeliharaan tanaman, dan (6) adanya atap plastik memberikan keuntungan (a) mencegah kerusakan karena hujan, (b) menghemat biaya penyiraman karena atap plastik mengurangi penguapan. Pelatihan ini bertujuan untuk mengenalkan dan mempraktekkan sistem pertanian vertikultur, sehingga dapat memotivasi masyarakat untuk mengaplikasikannya di rumah dan lingkungan tempat tinggalnya.

\section{PERMASALAHAN MITRA}

Sarana dan prasarana di Desa Salam Kecamatan Karangpandan tergolong cukup baik. Akses jalan pada Desa Salam terbuat dari beton dan sudah mencakup seluruh dusun yang ada di Desa Salam. Lebar badan jalan juga sudah cukup untuk menunjang aktivitas masyarakat di Desa Salam, karena dapat dilewati alat transportasi seperti truk, minibus, dan mobil. Akses jalan tersebut juga menjadi perhatian utama dalam pembangunan desa, karena sebagian besar penduduk di Desa Salam bermatapencaharian sebagai petani. Sehingga diharapkan dengan akses yang baik maka dapat menunjang peningkatan pendapatan petani.

Sarana dan prasarana lainnya untuk menunjang aktivitas masyarakat Desa Salam juga tergolong baik yaitu tempat beribadah, tempat olahraga yaitu lapangan sepakbola dan gedung badminton, serta balai desa. Selain itu masih banyak lagi sarana dan prasarana yang dibangun oleh masyarakat secara swadaya untuk mendukung kegiatankegiatan yang diadakan oleh masyarakat sekitar. Seperti peralatan pesta pernikahan, sound system, dan peralatan dapur umum yang dapat digunakan oleh masyarakat untuk menunjang kegiatankegiatan yang ada di Desa. Untuk sarana 
dan prasarana pendidikan, di Desa Salam juga sudah terbangun dengan baik tetapi belum lengkap.

Akses listrik juga sudah tersalurkan kepada semua warga di Desa Salam tetapi masih dengan rata-rata daya yang kecil per rumah tangga. Tetapi untuk penerangan jalan di Desa Salam masih sangat minim, sehingga kondisi di hampir semua dusun masih gelap di malam hari. Sedangkan untuk akses air bersih sudah terdistribusi dengan baik karena letak geografis Desa Salam yang berada di lereng pegunungan, sehingga air bersih berlimpah. Warga masyarakat menggunakan bak penampungan air kolektif yang dibangun oleh pemerintah desa untuk menyalurkan air bersih kepada semua rumah. Oleh karena itu, dapat dikatakan bahwa untuk menunjang pemenuhan kebutuhan air dan irigasi pertanian masyarakat di Desa Salam sarana dan prasarana sudah tersedia dengan baik, tetapi masih perlu untuk menambah dan memperbaiki guna mendukung semua kegiatan masyarakat Desa Salam.

Pada bidang kesehatan dan lingkungan, Di Desa Salam Kecamatan Karangpandan tersedia 1 poliklinik, 1 rumah bersalin, dan 6 posyandu untuk lansia dan balita. Untuk posyandu lansia dan balita di masing-masih dusun sudah terencana jadwal posyandu bulanan. Kebersihan di Desa Salam sangat dijaga oleh para warga, sering mengadakan gotong royong untuk pembangunan jalan, kerja bakti setiap hari Minggu pagi untuk membersihkan sampah yang berserakan di jalan serta membersihkan selokan di masing-masih RT yang dilakukan oleh warga.

Administrasi desa Salam dari tahun ke tahun cukup tertib karena pengarsipannya juga dilakukan secara rutin dan teratur. Kondisi ini dapat membentuk basis data yang teratur tertib administrasi. Bidang-bidang dalam administrasi Desa Salam terbagi antara lain PKK, Pembangunan Desa, Program pengembangan sumber daya manusia yang meliputi sosialisasi kepada masyarakat desa dengan memberikan pelatihan-pelatihan keterampilan meliputi menjahit, membuat olahan produk lokal, dan lain sebagainya.

Potensi unggulan Desa Salam dalam mengembangkan perekonomian antara lain usaha pertanian berupa padi, ubi, dan sayuran, usaha industri pengolahan pangan, usaha peternakan, dan usaha perdagangan. Potensi tersebut diperkaya dengan bidang sosial dan budaya yang masih menjunjung tinggi nilai-nilai Jawa, dan juga nilai gotong royong yang masih kental. Heterogenitas penduduk juga dibuktikan dengan adanya penduduk yang berasal dari luar pulau Jawa sehingga semakin banyak budaya yang dimiliki oleh masyarakat di Desa Salam.

Berdasarkan identifikasi kondisi di Desa Salam tersebut, maka dapat dirumuskan bahwa kajian ini beertujuan untuk mencari alternatif pengembangan lahan terbatas dengan sekaligus dapat memberdayakan peran serta masyarakat. Kajian ini akan menawarkan metode pembedayaan dengan memanfaatkan kondisi keterbatasan luas lahan.

\section{METODE: SOLUSI YANG DITAWARKAN}

Skema pemberdayaan Desa Sehat meliputi kegiatan (1) Pelatihan Pemberdayaan masyarakat, Pemberdayaan masyarakat/unit usaha, (3) Monitoring dan evaluasi (4) Pertemuan teknis petani, (5) Workshop oleh Komunitas, dengan rincian sebagai berikut: 


\begin{tabular}{|c|c|c|c|}
\hline No. & Program Kegiatan & Output & Indikator \\
\hline 1 & $\begin{array}{l}\text { Pelatihan Pemberdayaan } \\
\text { Masyarakat }\end{array}$ & $\begin{array}{l}\text { Ada } 2 \text { unit kegiatan } \\
\text { Pelatihan pemberdayaan di } \\
2 \text { dusun, dengan } \\
\text { pelaksanaan minimal } 4 \text { kali } \\
\text { pertemuan; durasi setiap } \\
\text { pertemuan adalah } 3 \\
\text { jam) }\end{array}$ & $\begin{array}{ll}\text { - } & \text { Pelaksanaan } \\
\text { minimal } 4 \text { kali } \\
\text { - } & \text { Laporan } \\
\text { pelaksanaan } \\
\text { harus lengkap } \\
\text { - } \quad \text { Basis data } \\
\text { kegiatan } \\
\text { dilakukan } \\
\text { melalui } \\
\text { dokumentasi } \\
\text { yang diunggah } \\
\text { pada media } \\
\text { akademik dan } \\
\text { sosial (research } \\
\text { gate dan you } \\
\text { tube) }\end{array}$ \\
\hline 2 & $\begin{array}{l}\text { Pemberdayaan } \\
\text { Masyarakat }\end{array}$ & $\begin{array}{l}\text { Adanya kegitan unit usaha } \\
\text { di } 2 \text { RT Dan munculnya } \\
\text { kegiatan usaha-usaha } \\
\text { lainya, }\end{array}$ & $\begin{array}{ll}\text { - } & \text { Pelaksanaan } \\
\text { minimal } 1 \text { unit } \\
\text { usaha di } 2 \text { RT } \\
\text { - } & \text { Laporan } \\
\text { pelaksanaan } \\
\text { harus lengkap } \\
\text { - } \text { Basis data } \\
\text { kegiatan } \\
\text { dilakukan } \\
\text { melalui } \\
\text { dokumentasi } \\
\text { yang diunggah } \\
\text { pada media } \\
\text { akademik dan } \\
\text { sosial (research } \\
\text { gate dan you } \\
\text { tube) }\end{array}$ \\
\hline 3 & $\begin{array}{l}\text { Monitoring dan } \\
\text { Evaluasi }\end{array}$ & $\begin{array}{l}\text { Stakeholder yang memiliki } \\
\text { kepentingan dalam } \\
\text { melakukan evaluasi dan } \\
\text { monitoring kegiatan }\end{array}$ & $\begin{array}{ll}- & \text { Pelaksanaan } \\
& \text { dilakukan } 1 \text { kali } \\
& \text { setiap semester } \\
& \text { (6 bulan) } \\
\text { - } & \text { Laporan } \\
& \text { evaluasi dan } \\
\text { monitoring } & \text { dapat diakses } \\
\end{array}$ \\
\hline 4 & $\begin{array}{l}\text { Pertemuan Teknis } \\
\text { Petani }\end{array}$ & $\begin{array}{l}\text { Terlaksanya pertemuan } \\
\text { teknis petani untuk sharing } \\
\text { pengalaman antar anggota } \\
\text { masyarakat yang dihadiri } \\
\text { oleh kelompok tani desa } \\
\text { setempat. }\end{array}$ & $\begin{array}{ll}\text { - } & \text { Pelaksanaan } \\
\text { dilakukan } \\
\text { minimal } 2 \text { kali } \\
\text { setiap semester } \\
\text { (6 bulan) } \\
\text { - } & \text { Laporan } \\
& \text { pelaksanaan } \\
\text { lengkap dan }\end{array}$ \\
\hline
\end{tabular}




\begin{tabular}{|c|c|c|c|}
\hline No. & Program Kegiatan & Output & Indikator \\
\hline & & & $\begin{array}{l}\text { dapat diakses } \\
\text { - } \text { Basis data } \\
\text { kegiatan } \\
\text { dilakukan } \\
\text { melalui } \\
\text { dokumentasi } \\
\text { yang diunggah } \\
\text { pada media } \\
\text { akademik dan } \\
\text { sosial }\end{array}$ \\
\hline 5 & $\begin{array}{l}\text { Workshop oleh } \\
\text { Komunitas }\end{array}$ & $\begin{array}{l}\text { Terlaksananya Workshop, } \\
\text { dan dihadiri minimal oleh } \\
50 \text { orang } \\
\text { partisipan dari berbagai } \\
\text { pihak, baik masyarakat desa } \\
\text { maupun mahasiswa yang } \\
\text { concern pada } \\
\text { pemberdayaan masyarakat. }\end{array}$ & $\begin{array}{ll}\text { - } & \text { Pelaksanaan } \\
\text { dilakukan } \\
\text { minimal } 2 \text { kali } \\
\text { setiap semester } \\
\text { (6 bulan) } \\
\text { - } & \text { Laporan } \\
\text { pelaksanaan } \\
\text { lengkap dan } \\
\text { dapat diakses } \\
\text { - Basis data } \\
\text { kegiatan } \\
\text { dilakukan } \\
\text { melalui } \\
\text { dokumentasi } \\
\text { yang diunggah } \\
\text { pada media } \\
\text { akademik dan } \\
\text { sosial }\end{array}$ \\
\hline
\end{tabular}

Program ini diharapkan dapat memberikan kontribusi bagi peningkatan perekonomian dan kesejahteraan masyarakat dan memberikan informasi yang menyeluruh mengenai Desa Sehat berdasar kondisi sosial-ekonomi masyarakat Desa Salam. Tahap pertama program ini adalah Pelatihan Pemberdayaan Masyarakat, diberikan sosialisasi mengenai cara tanam vertikultur organik. Lahan non produktif digunakan dengan optimal dengan pendekatan sistem vertikultur tersebut. Proses persiapan dimulai dari media tanam sampai bibit unggul digunakan dengan metode organik. Hal ini dilakukan agar dicapai hasil panen yang bebas dari unsure bahan kimiawi.
Komoditas hasil panen dapat dimanfaatkan masyarakat dengan dapat mereduksi dampak negatif dari materi kimiawi terhadap kesehatan.

Pada tahap kedua yaitu Pemberdayaan Masyarakat, diadakan pertemuan dengan kelompok tani setempat beserta simpul-simpul organisasi Desa Salam untuk memetakan organisasi pembibitan sayuran, pembuatan sistem vertikultur, penyiapan media tanam, pembesaran dan pemeliharaan sistem, hingga sistem pasca panen. Setelah peta organisasi disepakati dimulailah sistem plasma di antara warga masyarakat, sehingga pasokan bibit, media tanam, sistem vertikultur bisa berjalan beriringan secara harmonis. 
Penataan penanaman jenis sayuran juga mutlak dibagi, agar supaya tidak terjadi kelebihan stok ketika panen secara bersama-sama, misalnya Dusun Bulu berkonsentrasi menanam komoditas bayam merah organik sedangkan Dusun Salam berkonsentrasi menanam Cabai Keriting, sehingga proses barter bisa dilakukan ketika panen raya. Kelebihan stok akan dijual di Pasar Kampung Organik sehingga mengurangi ketergantungan warga masyarakat pada komoditas sayuran yang dijual di pasar.

Tahap ketiga adalah monitoring dan evaluasi, dimana proses keberlanjutan program dievaluasi oleh pihak aparatur Desa Salam . Proses tersebut akan bersinergi dengan tim pemberdaya bersama mahasiswa yang terlibat ketika ada masalah yang terjadi seperti mengganti bibit yang mati dengan bibit semai yang baru, sampai sosialisasi proses penyiraman mekanik secara sederhana. Pemanfaatan barang-barang limbah juga sangat diperlukan pada sub bagian ini.

Tahap keempat adalah pertemuan teknis petani. Kelompok tani melakukan diseminasi dan pemaparan proses yang telah dilaksanakannya, dengan saling berbagi informasi maka akan tercipta modal sosial masyarakat yang saling belajar antara mantra berdaya.

Poin terakhir adalah workshop oleh komunitas. bagian ini berisi unjuk pendapat tentang mekanisme baru yang digunakan dengan mekanisme konvensional yang biasa dan selama ini dilakukan.

\section{HASIL DAN PEMBAHASAN}

Bagian ini menjelaskan hasil dari kegiatan yang telah dicapai dalam program pemberdayaan desa sehat berbasis vertikultur di Desa Salam, Karangpandan. Evaluasi terhadap skema program yang dijalankan berpedoman pada Tabel 2:

\section{Survey tahap 1}

- Kegiatan yang dilakukan: pemetaan terhadap kondisi
Studi Kasus: Desa Salam Karangpandan Sukoharjo fisik dan kehidupan sosial yang ada di desa Salam

- Waktu: 1 hari (7 Mei 2015)

- Hasil yang dicapai: tim pengabdian masyarakat (abdimas) dapat mengidentifikasi kondisi lahan setempat (apa dan bagaimana tanaman yang cocok dikembangkan) dan mengeksplorasi informasi respon masyarakat setempat terhadap rencana program

- Tantangan/kendala: tim abdimas masih perlu mengadakan survey lanjutan

2. Survey tahap 2

- Kegiatan yang dilakukan: pemetaan lanjutan terhadap kondisi fisik dan kehidupan sosial yang ada di desa Salam. Pemetaan dilakukan dengan lebih komprehensif dengan melakukan focus group discussion (FGD)

- Waktu: 3 hari (20-22 Juni 2015)

- Hasil yang dicapai: tim pengabdian masyarakat (abdimas) dapat mengidentifikasi kondisi lahan setempat (apa dan bagaimana tanaman yang cocok dikembangkan) dan mengeksplorasi informasi respon masyarakat setempat terhadap rencana program

- Tantangan/kendala: tim abdimas masih perlu mengadakan survey lanjutan

3. Verifikasi hasil survey

- Kegiatan yang dilakukan: pemetaan lanjutan terhadap kondisi fisik dan kehidupan sosial yang ada di desa Salam. Pemetaan dilakukan dengan lebih komprehensif dengan melakukan focus group discussion (FGD) 
- Waktu: 22 Juni 2015 (di akhir survey tahap 2)

- Hasil yang dicapai: mengidentifikasi tanaman yang potensial dikembangkan di desa Salam, prospek bernilai ekonomi tinggi dan direspon baik oleh masyarakat setempat. Tim abdimas lebih fokus pada tanaman hias yang ramah lingkungan dan cukup mudah dikembangkan masyarakat setempat

- Tantangan/kendala: tim abdimas perlu melakukan beberapa evaluasi untuk menguji hasil tersebut

4. Sosialisasi pemberdayaan (sesuai hasil verifikasi)

- Kegiatan yang dilakukan: sosialisasi dilakukan di 2 RT dengan fokus pada pengembangan tanaman hias dan juga pengembangan media tanam

- Waktu: 28 Juni 2015

- Hasil yang dicapai: sosialisasi mendapatkan respon baik

- Tantangan/kendala: pelaksanaan dilakukan di bulan Ramadhan sehingga masyarakat masih belum segera mengembangkan

5. Evaluasi pasca sosialisasi awal

- Kegiatan yang dilakukan: melakukan evaluasi terhadap hasil sosialisasi dan melakukan persiapan sosialisasi lanjutan

- Waktu: 7 Agustus 2015

- Hasil yang dicapai: tim abdimas sudah lebih memfokuskan pada pengembangan tanaman hias yang ramah lingkungan dan sekaligus media tanamnya.
- Tantangan/kendala: perlu dilaksanakan sosialisasi lanjutan

6. Sosialisasi lanjutan

- Kegiatan yang dilakukan: melakukan sosialisasi lanjutan terhadap hasil sosialisasi pertama, sekaligus persiapan melaksanakan workshop

- Waktu: 9 Agustus 2015

- Hasil yang dicapai: persiapan workshop yang dilakukan dalam rangka memberikan pemahaman terhadap tata cara teknis pengembangan tanaman dan packaging media tanam

- Tantangan/kendala: persiapan workshop perlu memperhatikan respon masyarakat agar peminat banyak

7. Evaluasi sosialisasi lanjutan

- Kegiatan yang dilakukan melakukan evaluasi hasil sosialisasi lanjutan sekaligus persiapan melaksanakan workshop

- Waktu: 10 Agustus 2015

- Hasil yang dicapai: masyarakat tertarik pada packaging media tanam karena selama ini media tanam diproduksi secara sederhana dan belum memenuhi standar mutu kemasan

- Tantangan/kendala: perlu workshop dan FGD tentang bagaimana langkah teknis packaging dilakukan untuk media tanam

Berdasarkan hasil yang telah dicapai, maka tim abdimas akan mempersiapkan program pemberdayaan desa Sehat berbasis vertikultur di desa Salam, Karangpandan sebagai berikut: 
1. Melakukan pertemuan dengan warga berkaitan dengan langkah konkrit dari program pemberdayaan ini. Membentuk semacam

kepanitiaan/kepengurusan secara kolektif dan sukarela di kalangan masyarakat untuk memudahkan koordinasi

- Kegiatan yang dilakukan: Tim abdimas melakukan pertemuan dengan beberapa tokoh kunci di warga setempat. Diskusi dengan tokoh kunci bertujuan untuk mencari format yang sesuai untuk penggerak pemberdayaan masyarakat Studi Kasus: Desa Salam Karangpandan Sukoharjo

- Waktu: 19-September-2018

- Hasil yang dicapai: Tokoh/informan kunci mengungkapkan bahwa format yang sesuai untuk menstimulasi pemberdayaan desa sehat di desa Salam adalah pemeberdayaan ibuibu PKK.

- Tantangan/kendala: pada saat informan mengarahkan untuk menempatkan ibu-ibu PKK sebagai stimulan pemberdayaan, pihak internal ibu-ibu PKK belum menunjukkan tingkat kesiapan yang memadai

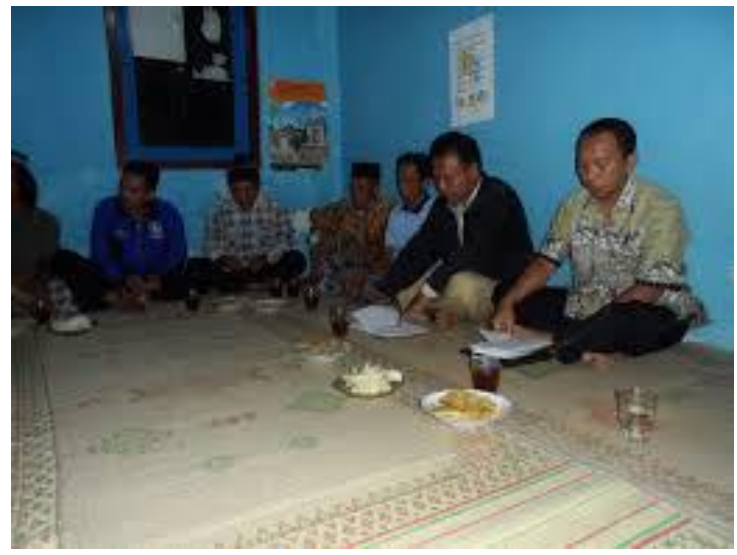

Gambar 1

2. Melanjutkan kembali pertemuan lanjutan I dengan tokoh/informan kunci dan sekaligus menghadirkan subjek yaitu forum ibu-ibu PKK. Pertemuan lanjutan I ini mencoba mengkonfirmasi tingkat kesiapan forum ibu-ibu PKK dalam persiapan posisi mereka sebagai penggerak pemberdayaan.

- Kegiatan yang dilakukan: Tim abdimas melakukan pertemuan dengan beberapa tokoh forum ibu-ibu PKK di warga setempat. Diskusi dengan forum ibu-ibu PKK sekaligus meminta konfirmasi kesiapan. Kegiatan ini juga akan menjadi embrio format teknis

- Waktu: 26-September-2018

- Hasil yang dicapai: Forum ibu-ibu memang belum menyatakan kesiapan dengan pasti namun mereka bersedia untuk mencoba dan menyiapkan format teknis.

- Tantangan/kendala: Masih ada keraguan dari forum ibuibu PKK 


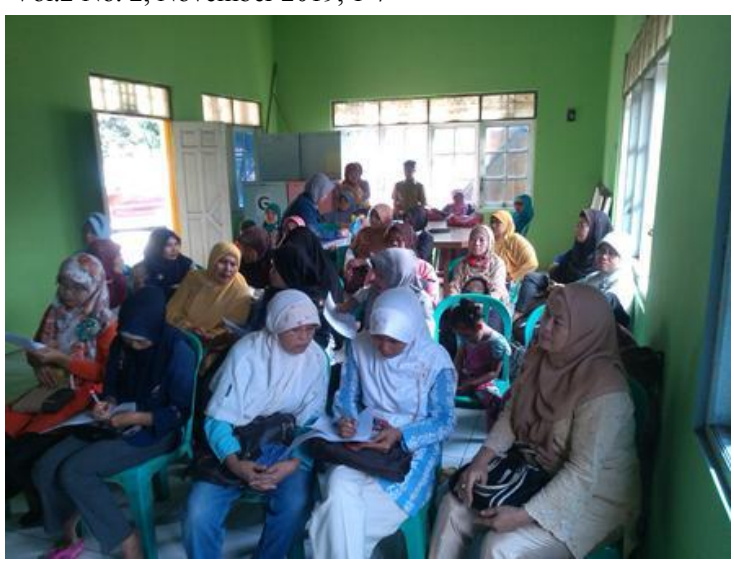

Gambar 2

3. Melanjutkan kembali pertemuan lanjutan II dengan tokoh/informan kunci dan sekaligus menghadirkan subjek yaitu forum ibu-ibu PKK. Pertemuan lanjutan II ini mencoba menyusun format teknis (blue print) bagi pemberdayaan ibu-ibu PKK

- Kegiatan yang dilakukan: Tim abdimas melakukan pertemuan untuk menyusun format teknis dan disosialisasikan kepada ibuibu PKK.

- Waktu: 3-Oktober-2018

- Hasil yang dicapai: Ada beberapa format teknis yaitu 1) Membuat kelompok ibuibu PKK (4 orang per kelompok); 2) Memberi arahan teknis kepada ibu-ibu untuk mengembangkan tanaman hias jenis anggrek dan kaktus.

- Tantangan/kendala: Masih memerlukan tahap evaluasi

4. Melanjutkan kembali pertemuan lanjutan III untuk melakukan evaluasi terhadap pelaksanaan penanaman anggrek dan kaktus vertikultur

- Kegiatan yang dilakukan: Tim abdimas melakukan pertemuan untuk mengevaluasi kegiatan ibuibu PKK.
- Waktu: 17-Oktober-2018

- Hasil yang dicapai: Sudah terdapat perkembangan usaha yang dilakukan oleh komunitas ibu-ibu PKK

- Tantangan/kendala:

Memerlukan workshop terutama untuk melakukan proses pemasaran sekaligus membina keberlanjutan program ini

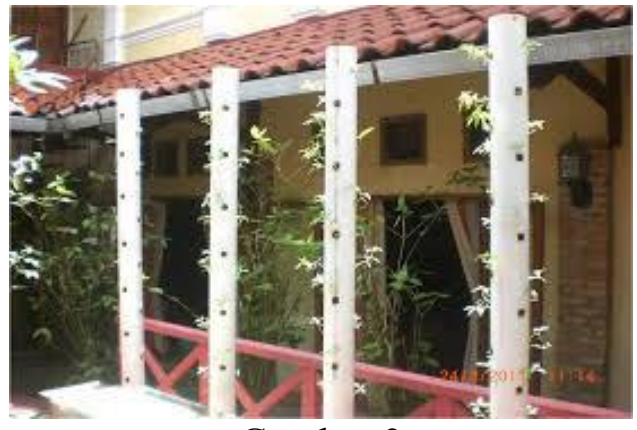

Gambar 3

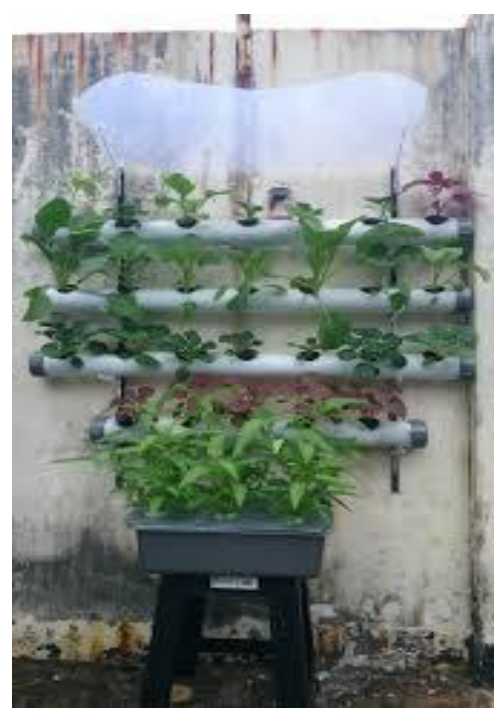

Gambar 4

5. Melakukan workshop teknis berkaitan dengan proses pencarian bahan, proses pembuatan, proses pengemasan (packaging) dan sampai pada proses pemasaran dari media tanam. Media tanam yang diproduksi akan difokuskan pada media tanam untuk tanaman hias (seperti anggrek, kaktus) 
Yogi Pasca Pratama, Bhimo Rizky Samudro, Albertus Maqnus Soesilo Skema Model Vertikultur dan Implikasinya Bagi Pemberdayaan Masyarakat

- Kegiatan yang dilakukan: Tim abdimas mengadakan workshop

- Waktu: 26-Oktober-2018

- Hasil yang dicapai: Kegiatan workshop berfokus pada keberlanjutan penyediaan bahan, proses pengelolaan, pola pengemasan dan pemasaran

- Tantangan/kendala:

Terdapat kendala teknis untuk masalah pengemasan dan pemasaran.

Bagan di bawah ini mencoba menjelaskan tentang

6. Tim abdimas melakukan monitoring dan evaluasi terhadap program ini. Evaluasi dan monitoring diperlukan untuk memastikan apa dan bagaimana keberlanjutan program desa sehat dengan basis vertikultur.

- Kegiatan yang dilakukan: Tim abdimas mengadakan rapat evaluasi dan monitoring

- Waktu: 4-November-2018

- Hasil yang dicapai: Tim abdimas relatif mampu mengarahkan masayarakat (ibu-ibu PKK) untuk mencari aktivitas alternatif yang bermanfaat dan sehat bagi lingkungan

- Tantangan/kendala: Masih terdapat kendala pada proses
Studi Kasus: Desa Salam Karangpandan Sukoharjo pemeliharaan tanaman dan sekaligus juga pola pemasarannya

7. Tim abdimas melakukan rapat koordinasi akhir sebelum penyusunan laporan abdimas

- Kegiatan yang dilakukan: Tim abdimas mengadakan rapat koordinasi akhir untuk embrio penyusunan laporan akhir

- Waktu: 14-November-2018

- Hasil yang dicapai: Tim abdimas menyusun arah dan aspek yang akan dipertimbangkan untuk kerangka penyusunan laporan akhir dan produk luaran (draft dokumen dan draft jurnal ilmiah)

- Tantangan/kendala: Masih terdapat kendala pada proses pemeliharaan tanaman dan sekaligus juga pola pemasarannya

Setelah melalui proses kegiatan di atas, tim abdimas menyusun beberapa alternatif pola pemberdayaan masyarakat. Secara spesifik skema ini merupakan kontribusi luaran kegiatan ini, dimana proses pemberdayaan masyarakat berbasis pada peran ibu-ibu PKK dan teknis penanaman model vertikultur di desa Salam. 


\section{Opsi skema 1}

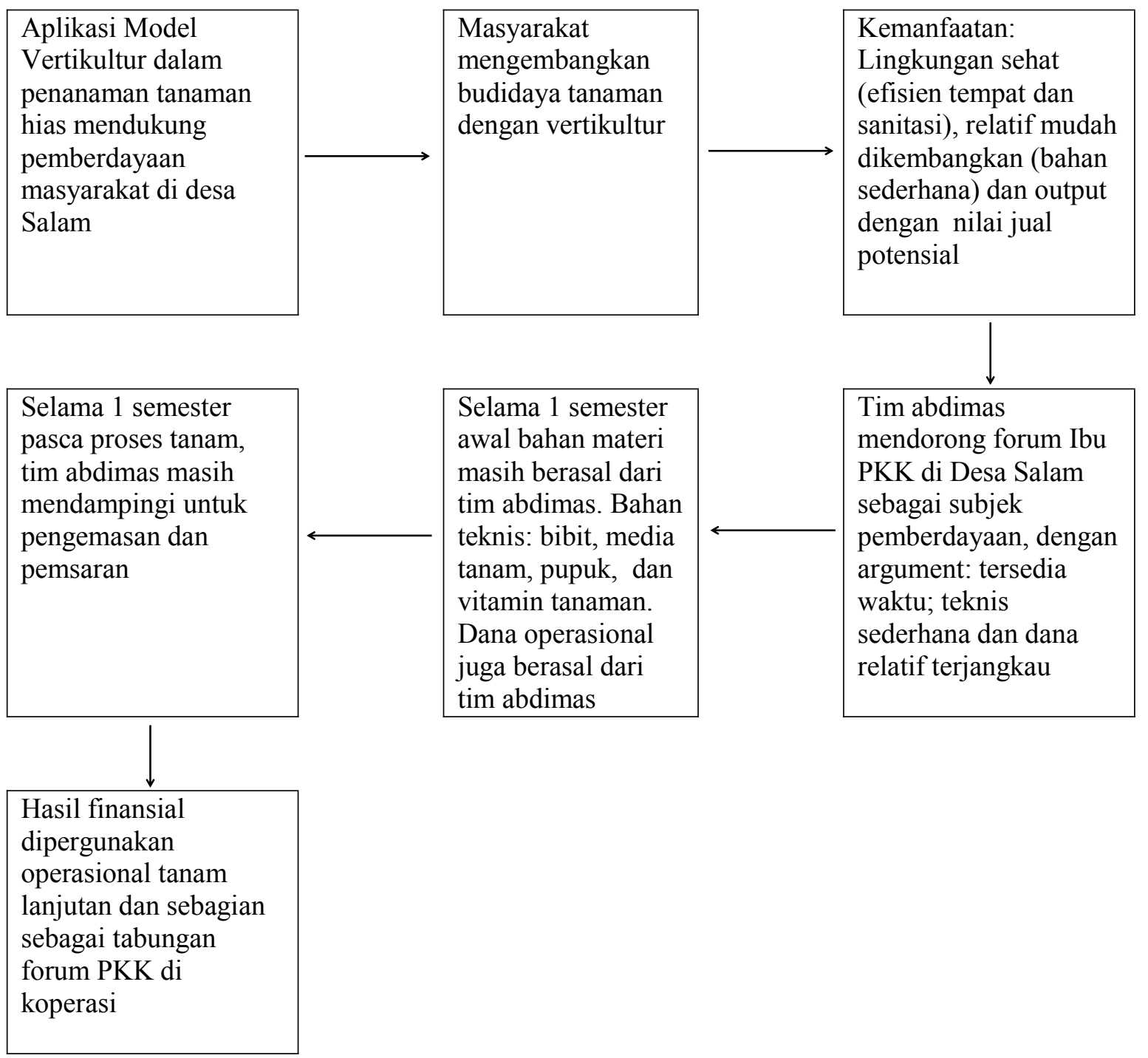

Pada skema pemberdayaan opsi 1 , tim abdimas dilakukan pendampingan dari awal pembentukan sampai pada pemasaran produk. Namun untuk proses keberlanjutan operasional tanam selanjutnya, tim abdimas memberi hak otonom kepada forum ibu PKK dalam pengelolaan dan alokasi dananya.
Artinya dalam skema opsi 1, tim abdimas lebih menitikberatkan pada bagaimana mendorong peran ibu PKK dan membantu format teknis model vertikultur ini untuk diterapkan. Namun tim abdimas memberi hak otonom tentang pengelolaan dana untuk tanam selanjutnya. 


\section{Opsi skema 2}

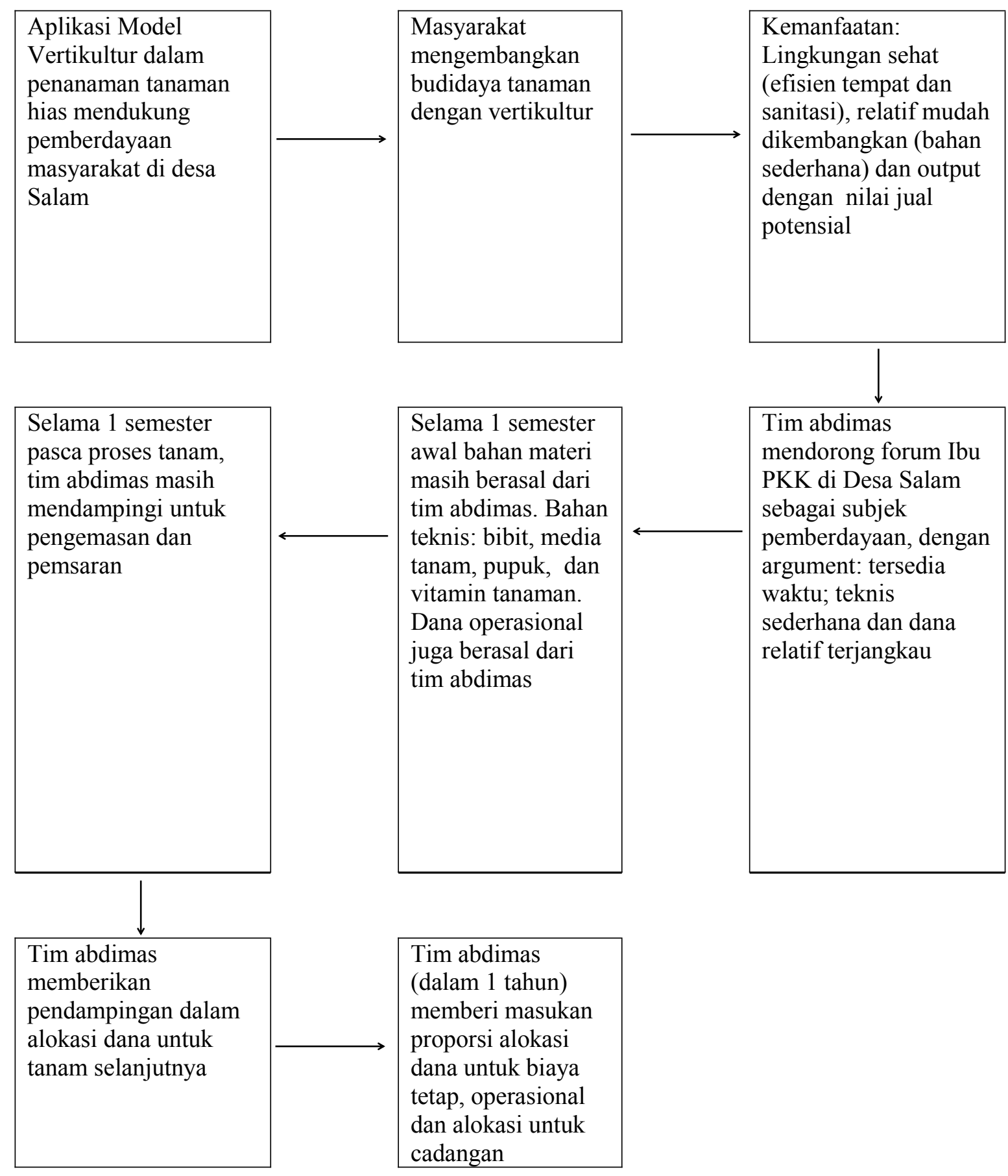

Pada skema pemberdayaan opsi 2, tim abdimas memberikan pendampingan sampai pada aspek pengelolaan dana/finansial pasca tanam fase pertama. Dalam posisi ini, tim abdimas belum melepas pengelolaan program secara otonom sampai 1 tahun dari program dimulai. Dalam skema ini, titik berat tim abdimas adalah pada pengembangan budaya pengelolaan finansial yang tepat guna. Artinya, tim abdimas mengarahkan forum ibu PKK untuk benar memanfaatkan dan mengalokasikan hasil penjualan fase tanam pertama untuk kegiatan produktif. Hal ini juga mendorong ibu PKK untuk menyisihkan sebagian dana sebagai tabungan bersama. Skema opsi 2 ini mencoba meminimalisir pola konsumtif di kalangan ibu PKK dan sekaligus memberdayakan mereka untuk mengalokasikan waktu lebih produktif (.) 


\section{KESIMPULAN DAN SARAN}

Kesimpulan dalam pelaksanaan program ini:

1. Program ini memberikan alternatif skema untuk alternatif pengembangan lahan terbatas dengan sekaligus dapat memberdayakan peran serta masyarakat.

2. Program ini mengenalkan dua opsi skema pemberdayaan berbasis gender dan sekaligus menggunakan model vertikultur. Skema 1 menitikberatkan pada fondasi teknis pemberdayaan dan otonomi pengelolaan (terutama pendanaan); sementara skema 2 menitikberatkan pada keberlanjutan dan penanaman budaya alokasi waktu produktif dan meminimalisir pola konsumtif di kalangan ibu PKK desa Salam

Saran terhadap hasil yang telah dicapai dan program ke depan mencakup:

Monitoring dan evaluasi setiap pelaksanaan tahapan program, sosialisasi sampai workshop teknis, diperlukan demi menjaga kualitas dan keberlanjutan program ini. Tim abdimas tetap perlu mengadakan public hearing dan FGD untuk tetap memelihara respon dan kepercayaan baik dari masyarakatTim abdimas harus tetap perlu mengadakan identifikasi berkesinambungan agar dapat melihat potensi lain yang dapat dikembangkan Tim abdimas perlu untuk melihat perkembangan program ini, baik secara teknis dan finansial sekitar 2 tahun ke depan pasca fase tanam pertama

\section{DAFTAR PUSTAKA}

Ariani, A. \& Tiangsa S. 2007. Prevalensi

Obesitas pada Anak Sekolah

Dasar di Kota Medan. Majalah

Kedokteran Nusantara 40 (2): 8689.

Aurum, M. 2005. Pengaruh Jenis Media Tanam dan Pupuk Kandang Terhadap Setek
Sambang Colok (Aerva

sanguinolenta Blume). Skripsi.

Program Studi Agronomi,

Fakultas Pertanian, Intitut

Pertanian Bogor.

Buckman dan Nyle.C. Brady., 1982. Ilmu Tanah. Bhatara Karya Aksara. Jakarta

Darmawan, J dan J.S. Baharsyah. 1983. Dasar-Dasar Ilmu

Fisiologi Tanaman. Suryadaru Utama. Semarang.

Darmawan. 2009. Budidaya Tanaman Kailan.Kanisius. Yogyakarta

Dartius. 1990. Fisiologi

Tumbuhan 2. Fakultas Pertanian Universitas Sumatera Utara, Medan. $125 \mathrm{hlm}$.

De Boodt, M. Dan D. Verdonck. 1972. The Properties of Substrates in Horticulture. Acta Horticultural. Departemen Pertanian. 2015. Impor Ekspor Buah dan Sayuran di Indonesia. Diakses dari www.kementrianpertanian.go.id tanggal 23 November 2015

Dorais, M., A.P. Papadopoulos, and A. Gosselin. 2001. Influence of Electric Conductivity Management on Green House Tomato Yield and Fruit Quality. Journal Agronomi. Australia.

Effendy. 2011. Drainase Untuk Meningkatkan Kesuburan Lahan Rawa. Jurusan Teknik Sipil Politeknik Negeri Sriwijaya.PILAR Jurnal Teknik Sipil, Vol. 6, No. 2, September 2011

Endra, S., M. Rahmawati., S. Imran. 2014 Pengaruh Komposisi Media Tanam dan Konsentrasi Pupuk Daun Terhadap Pertumbuhan dan Hasil Tanaman Selada (Lactuca sativa L.). Jurnal Floratek.Program Studi Agroteknologi, Fakultas Pertanian, Universitas Syiah Kuala.

Kartini, 2015. Berkebun Sayur dan Buah Organik di Sekolah Dasar dengan Teknik Vertikultur Sebagai Upaya 
Yogi Pasca Pratama, Bhimo Rizky Samudro, Albertus Maqnus Soesilo Skema Model Vertikultur dan Implikasinya Bagi Pemberdayaan Masyarakat

Pemanfaatan Lahan Kosong dan Menumbuhkan Kecintaan Siswa Pada Sayur dan Buah. Laporan Studi Kasus: Desa Salam Karangpandan Sukoharjo Pengabdian Kepada Masyarakat, Unsoed, Purwokerto..

\section{Lampiran 1.}

Peta Lokasi Pemberdayaan (Desa Salam, Kec. Karangpandan, Kab. Karanganyar)

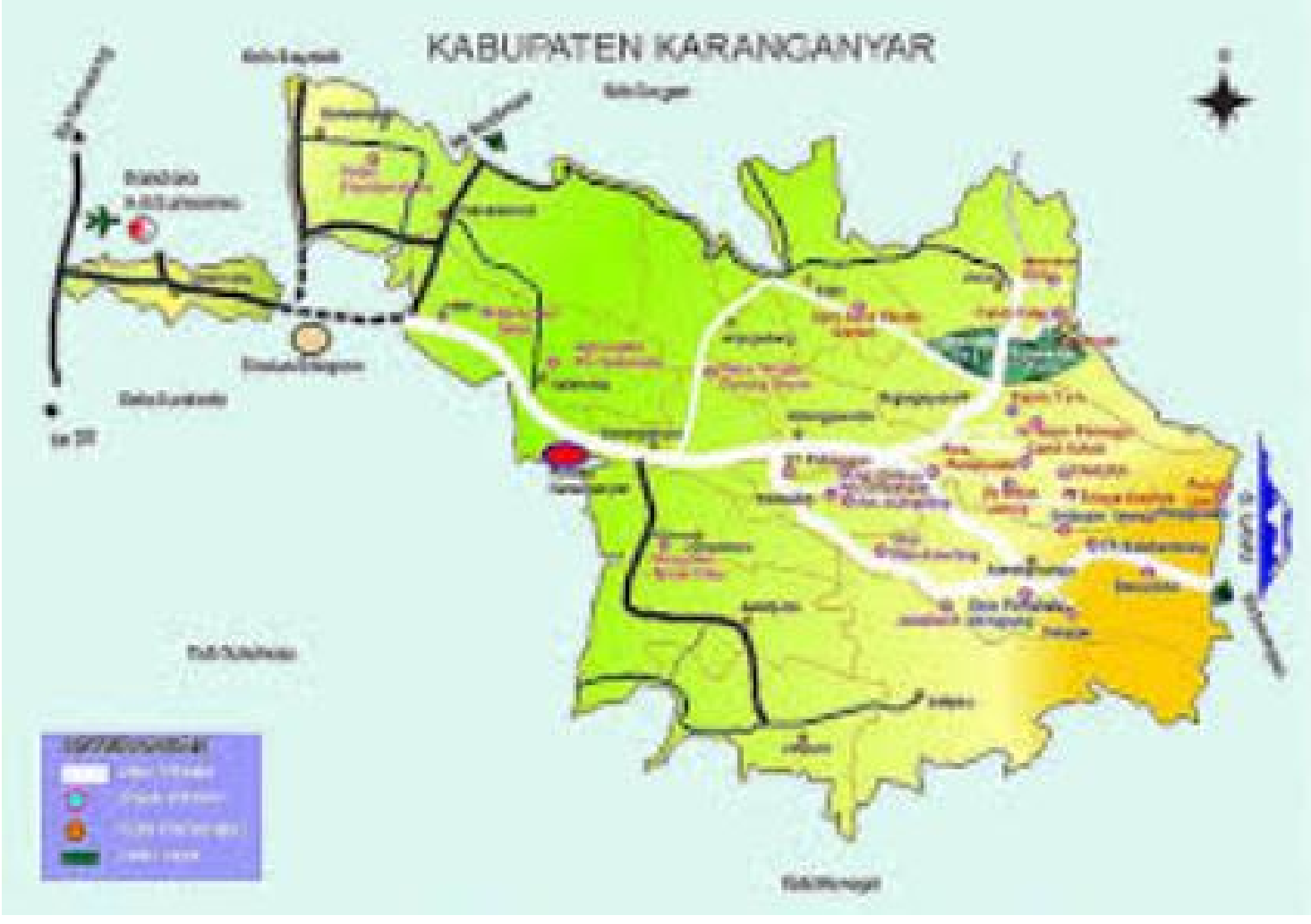

Sumber: www.karanganyar.go.id

\section{Lampiran 2.}

\section{Contoh sistem vertikultur}
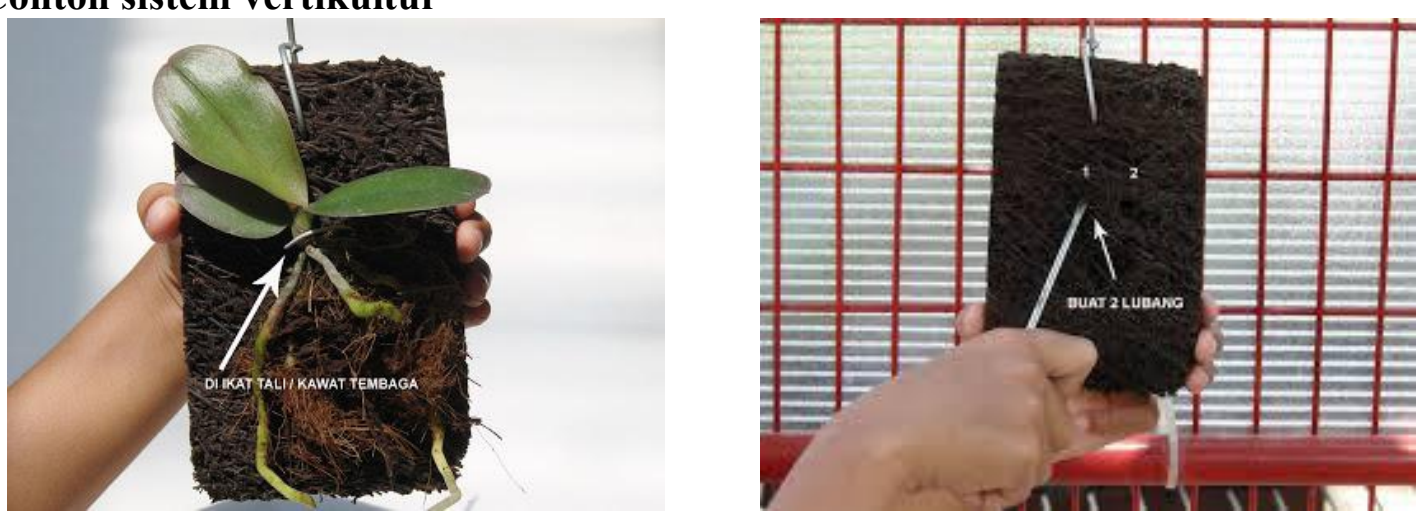

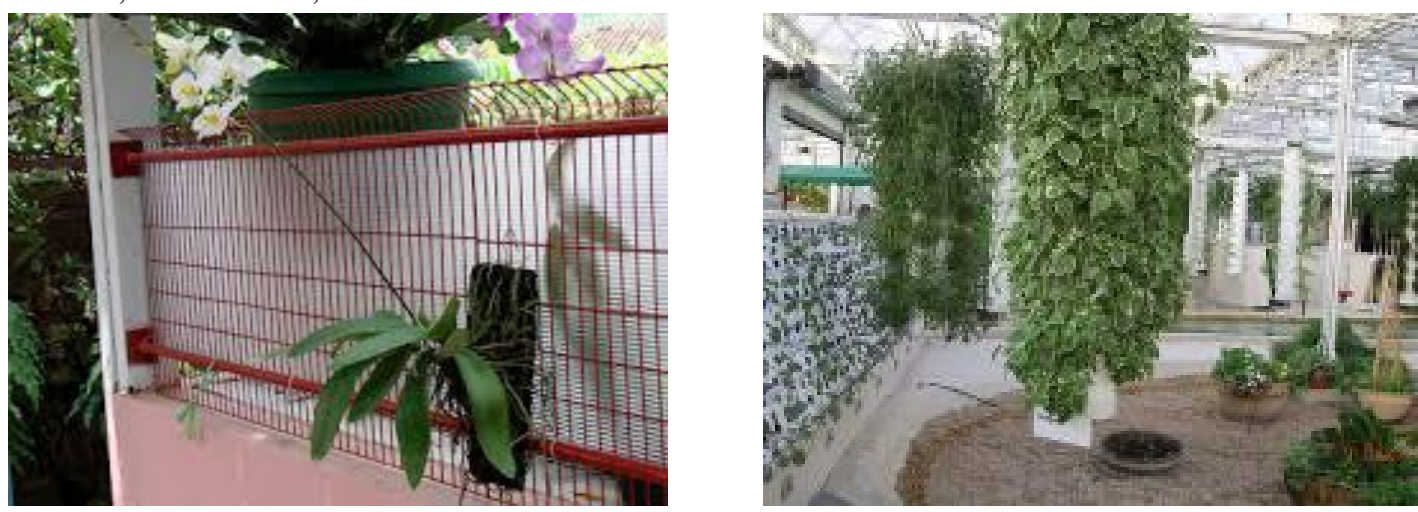

Teknik pertanian vertikultur diarahkan untuk membudidayakan tanaman semusim atau berumur pendek, seperti sayuran. Aneka sayuran yang dapat ditanam antara lain seledri, selada, kangkung, bayam, kemangi, sawi, caisim atau kailan. Pohon cabai, tomat, atau terong, juga mudah sekali tumbuh dengan cara ini. Jenis tanaman obatobatan atau tanaman hias pun potensial untuk dicoba.

\section{MATERI/ALAT YANG DIPERLUKAN}

1. Pipa paralon

2. Gergaji besi

3. Penggaris atau meteran

4. Lampu teplok

5. Kayu bulat

6. Pupuk kompos/kandang

7. Tanah gembur

8. Kotak semai untuk benih 